Egyptian Journal of Rabbit Science, 30(1): 75- 92 (2020)

\title{
UTILIZATION OF Moringa oleifera AS A NEW RABBITS FEED. 4- EFFECT OF DIETARY INCLUSION OF Moringa oleifera HAY ON BLOOD CONSTITUENTS AND HISTOPATHOLOGICAL STRUCTURE OF GROWING RABBITS.
}

\author{
M. S. Abd-Allah:, H. Ibrahim ; H. M. El-Kelawy and M.N. El-Gafaary \\ Department of Animal and Poultry Production, Faculty of Technology \& \\ Development, Zagazig University, Zagazig, Egypt.
}

e.mail: drhassan 2105@yahoo.com

\begin{abstract}
A total number of 90 weanling New Zealand White (NZW) rabbits of both sexes, 5 weeks old with an average initial live body weight of $550.5 \pm 20.23(\mathrm{~g})$ were used in this study to evaluate the effect of dietary inclusion of different levels of moringa hay (which composed of leaves $50 \%+$ twigs 50\%) as a partial substitute for alfalfa hay on blood constituents and histopathological structure. The animals were randomly allotted into three experimental groups (30 each). The first group $(A)$ was fed the basal diet as control, while the second $(B)$ and third groups $(C)$ were fed diets containing Moringa oleifera hay as a replacement of $50 \%$ and $75 \%$ of alfalfa hay in the basal diet, respectively throughout the growing period (5-13 week of age).

The obtained results showed that as a substitute for alfalfa hay in the rabbits fed Diet $C$ increased diet showed normal hisosignificantly $(P<0.01)$ haemoglobin morphological structures as control. (Hb) and hematocrit (Hct) as Testis of male rabbits fed Diet A

compared with those fed Diet $B$ and Diet A (control group). However, the differences in red blood cell (RBCs), white blood cell (WBCs), platelet $(P l t)$, neutrophils, lymphocytes, mean corpuscular volume (MCV) and mean corpuscular haemoglobin (MCH) were not significant. Moreover, all values of blood haematological parameters are within the normal range for healthy rabbits. The differences in total protein, albumin, globulin, $A / G$ ratio, aspartate amino transferase (AST), alanine amino transferase (ALT), bilirubin, urea-N and creatinine among the experimental groups of growing NZW rabbits fed different level of Moringa oleifera hay and control group were not significant. Sections from spleen, liver and kidneys of rabbits fed different level of Moringa oleifera hay (leaves +twigs)
\end{abstract} (n) 
(control), Diet B and Diet $C$ showed of protein for feeding growing rabbits normal spermatogonia, spermatocytes and could be added in the diet at levels and spermato cytogenesis processes. up to $15 \%$ to replace about $75 \%$ of Sections of ovaries of female growing alfalfa hay without any adverse effects rabbits fed Diet $B$ and Diet $C$ revealed on blood constituents and structure activated ovarian function with the of growing NZW rabbits. presence of primordial and growing Key word: Moringa oleifera, feeding, follicles, together with normal stromal blood constituents, growth structures as in the control (rabbits fed Performance, $\operatorname{diet} A)$.

Conclusively, the results of the present study demonstrated that, Moringa oleifera hay (leaves+ twigs) is supportive as unconventional source

\section{INTRODUCTION}

In Egypt as in the other developing countries, there is a severe shortage of animals feeds and its high cost represented the major problems for the shortage of animal protein sources in human food. Limited land resources and the high competition between human and livestock animals for high quality grain and protein supplements are the major contributors to nutrient deficiencies. Therefore, efforts have been made towards solving feeds shortage by improving the conventional sources and investigating more unconventional feeds for availability in animal feeds.

Moringa oleifera is the most widely cultivated species in the family moringaceae. It is rich in antioxidants, has high capacity to scavenge free radicals and play a significant role in reducing mortality and mobility due to cancer, heart diseases and other chronic illness. Moringa oleifera leaves became popular as a natural leaf powder supplement, although the pods, root, bark, flowers, seeds and fruits are also edible.

The moringa leaves contain high amount of $\beta$-carotene, protein, vitamin $\mathrm{C}$, calcium and potassium and serve as a good source of natural antioxidant which enhance the shelf-life of fat containing foods due to the presence of various types of antioxidant compounds such as ascorbic acid, flavonoids, phenolics and carotenoids also, moringa leaves are rich in, essential amino acids (Siddhuraju 
and Becker 2003, Bennett et al. 2003, Aslam et al. 2005, Manguro and Lemmen 2007, Amaglo et al. 2010 and Gowrishankar et al. 2010).

Therefore, the present study was carried out to evaluate the effects of inclusion of moringa hay (leaves and twigs) at different levels in the diet to substitute alfalfa hay on blood constituents and histopathological structure of growing NZW rabbits under Egyptian condition.

\section{MATERIALS AND METHODS}

The experimental work of the present study were carried out at the Rrabbits Research Unit, Department of Animal and Poultry Production, Faculty of Technology and Development, Zagazig University, Zagazig, Egypt. The experimental work was initiated in December 2015 and terminated in September 2016. The laboratory work was performed at Central Lab for Soil, Foods and Feedstuffs (International accredited Laboratory, has ISO 17025, since 2012) belongs to Faculty of Technology \& Development, Zagazig University, Zagazig, Egypt.

A total number of 90 weanling New Zealand White rabbits of both sexes, 5 weeks old with an average initial live body weight $550.5 \pm 20.23 \mathrm{gm}$ were used in this study to evaluate effects of dietary inclusion of different levels of moringa hay (leaves(50\%)+twigs(50\%)) on blood constituents and histo-pathological structure. The growing rabbits were allotted to three experimental groups (30 each) which were fed three different diets.

Group (A) was fed a basal pelleted diet. Group (B) was fed a diet contained $10 \%$ Moringa oleifera hay as a substituted for $50 \%$ alfalfa hay in the basal diet. Group (c) was fed a diet contained $15 \%$ Moringa oleifera hay as a substituted for $75 \%$ alfalfa hay in the basal diet. All the experimental diets were iso nitrogenous and iso energetic.

Moringa plants were cultivated at research farm of faculty of technology and development, Zagazig University. All plants were first harvested at 90 days of growth and each 45 days for the following successive cuts. Representative samples of the air- dried moringa leaves and twigs were taken for chemical

analysis, also samples of feed ingredients of the experimental diets were taken for chemical analysis to determine crude protein, crude fiber, ether extract, nitrogen free extract, calcium and phosphorus according to the methods of AOAC (1995).Chemical analysis was performed in the Central Lab for Soil, Foods and 
Feedstuffs ( International accredited Lab, since 2012 and has ISO 17025), Faculty of Technology\& Development, Zagazig University, Egypt.

The diets were formulated to meet the nutrient requirements of growing rabbits according to NRC (1977). The diet were mixed and pelleted at a commercial feed mill of Atmida, Meet Ghamr, Dakahlia Governorate, Egypt. Chemical analysis of alfalafa hay and Moringa oleifera hay (leaves (50\%) and twigs (50\%)) is presented in Table 1. Ingredients and chemical composition of the three experimental pelleted diets are shown in Table 2.

The animals were housed in flat deck batteries, provided with galvanized feeders and automatic drinkers. The growing rabbits were housed (each 3 rabbits together) in wire cages $(50 \times 55 \times 40 \mathrm{~cm})$. Buck rabbits were housed separately in individual cages $(50 \times 60 \times 40 \mathrm{~cm})$. All batteries were located in a naturally ventilated room. All rabbits were provided with food pellets and drinking water ad libitum throughout the experimental period.

At the termination of the experimental period (13 weeks of age), blood samples ( $5 \mathrm{ml} /$ each rabbit) were collected at slaughtering of growing rabbits. Each sample was divided into two tubes. The first tube was heparinized and the second was non-heparinized. All animals were kept under the same management and hygienic conditions. The heparinized blood samples were used to test hematological parameters.

Table (1): Chemical analysis of alfalafa hay and Moringa olifera hay (leaves and twigs)

\begin{tabular}{|c|c|c|c|c|}
\hline $\begin{array}{l}\text { Chemical } \\
\text { analysis }\end{array}$ & $\begin{array}{c}\text { Alfalafa } \\
\text { hay } \%\end{array}$ & $\frac{\text { Moringa ol }}{\text { Leaves }}$ & $\frac{\operatorname{era~hay,~\% ~}}{\text { Twigs }}$ & $\begin{array}{c}\text { Moringa hay } \\
\text { (leaves 50\% + twigs 50\%) }\end{array}$ \\
\hline Dry matter & 10.93 & 8.03 & 9.14 & 8.58 \\
\hline Crude protein & 14.8 & 24.4 & 6.2 & 15.3 \\
\hline Ether extract & 2.2 & 5.2 & 3.2 & 4.2 \\
\hline Crude fiber & 28.2 & 19.2 & 43.0 & 31.1 \\
\hline $\begin{array}{l}\text { Nitrogen free } \\
\text { extract }\end{array}$ & 34.9 & 34.2 & 29.1 & 31.65 \\
\hline Ash & 8.97 & 8.97 & 9.36 & 9.17 \\
\hline Total & 100 & 100 & 100 & 100 \\
\hline
\end{tabular}


Table (2): Ingredients and chemical analysis of the experimental pelleted diets fed to NZW rabbits.

\begin{tabular}{|c|c|c|c|}
\hline Ingredients & Diet A(control) & Diet B* & Diet C** \\
\hline Yellow corn & 17.0 & 17.0 & 17.0 \\
\hline Barley & 18.0 & 18.0 & 18.0 \\
\hline Wheat bran & 26.0 & 26.0 & 26.0 \\
\hline Soybeans & 16.0 & 16.0 & 16.0 \\
\hline Alfalfa hay & 20.0 & 10.0 & 5.0 \\
\hline \multicolumn{4}{|l|}{ Moringa oleifera hay } \\
\hline Leaves & 00.0 & 5.0 & 7.50 \\
\hline Twigs & 00.0 & 5.0 & 7.5 \\
\hline Limestone & 2.0 & 2.0 & 2.0 \\
\hline Sodium chloride & 0.5 & 0.5 & 0.5 \\
\hline Premix* & 0.3 & 0.3 & 0.3 \\
\hline DL-Methionine & 0.1 & 0.1 & 0.1 \\
\hline Anti Mycotoxins & 0.1 & 0.1 & 0.1 \\
\hline Total & 100.0 & 100.0 & 100.0 \\
\hline \multicolumn{4}{|l|}{ Chemical analysis: } \\
\hline Dry matter & 11.78 & 12.62 & 11.44 \\
\hline Crude protein & 17.49 & 17.65 & 17.83 \\
\hline Ether extract & 3.04 & 3.24 & 3.35 \\
\hline Crude fiber & 11.02 & 11.01 & 10.99 \\
\hline Nitrogen free extract & 46.34 & 48.26 & 48.26 \\
\hline Ash & 10.33 & 7.22 & 8.13 \\
\hline $\mathrm{Ca}$ & 1.02 & 1.01 & 1.01 \\
\hline $\mathrm{P}$ & 0.51 & 0.56 & 0.57 \\
\hline Laysine & 0.92 & 1.15 & 1.28 \\
\hline Meth+cysteine & 0.54 & 0.69 & 0.76 \\
\hline \multicolumn{4}{|c|}{$\begin{array}{l}\text { *one kilogram of premix provides: Vit. A } 12000 \mathrm{IU} \text {, Vit. } \mathrm{D}_{3} 2000 \mathrm{IU} \text {, Vit E } 10 \mathrm{mg} \text {, Vit. } \mathrm{K}_{3} \\
2 \mathrm{mg} \text {, Vit } \mathrm{B}_{1} 1 \mathrm{mg} \text {, Vit } \mathrm{B}_{2} 5 \mathrm{mg} \text {, Vit. } \mathrm{B}_{6} 1.5 \mathrm{mg} \text {, Vit. } \mathrm{B}_{12} 10 \mathrm{mg} \text {; Niacin } 30 \mathrm{mg} \text {, Pantothenic acid } \\
10 \mathrm{mg} \text {; Folic acid } 1 \mathrm{mg} \text {, Choine } 250 \mathrm{mg} \text {, Biotin } 50 \mathrm{mg} \text {, Copper } 5 \mathrm{mg} \text {, Manganese } 60 \mathrm{mg} \text {, Zino } \\
50 \mathrm{mg} \text {, Iron } 30 \mathrm{mg} \text {, Iodine } 0.3 \mathrm{mg} \text { Selenium } 0.1 \mathrm{mg} \text { and Cobalt } 0.1 \mathrm{mg} \text {. } \\
\text { Group A: was fed a basal pelleted diet. } \\
\text { Group B: was fed a diet contained } 10 \% \text { Moringa oleifera hay as a substituted for } 50 \% \text { alfalfa } \\
\quad \text { hay in the basal diet. } \\
\text { Group C: was fed a diet contained } 15 \% \text { Moringa oleifera hay as a substituted for } 75 \% \text { alfalfa } \\
\quad \text { hay in the basal diet. }\end{array}$} \\
\hline
\end{tabular}


Non-heparinized blood samples were immediately centrifuged at 3000 r.p.m. for 15 minutes and serum was separated, frozen under $-20^{\circ} \mathrm{C}$, and kept for biochemical analysis.

Red blood cells (RBCs), white blood cells (WBCs) counts and hemoglobin (Hb) concentration were determined as described by Emad El-Eslam (1997). RBCs and WBCs were counted on bright line hemocytometer using light microscope at $20 \mathrm{X}$ magnification. Blood samples were diluted 200 times with a physiological saline $(0.9 \% \mathrm{NaCl}$ solution) before counting RBCs and 20 times with a diluting fluid (1\% acetic acid and few drops of Leishman's stain) before counting WBCs. $\mathrm{Hb}$ concentration was determined according to Sahly method using $10 \% \mathrm{HCl}$ and distilled water. The basic principle is that hemoglobin is converted into acid hematin, which is compared with the standard hematin by the hemocytometer. Serum levels of total protein and albumen were determined according to Henry (1964) and Doumas et al. (1971), respectively, using commercial kits (Diamond diagnostics). The globulin value was obtained by subtracting the value of albumen from the corresponding value of total protein. The activity of aspartate aminotransferase (AST) and alanine amino-transferase (ALT) were assayed according to Reitman and Frankel (1957). Urea-N and creatinine levels were determined using commercial kits (Diamond diagnostics) according to the method of Patton and Crouch (1977) and Henry (1974), respectively.

Spleen, liver, kidney, testis and ovary were excised from male and female growing rabbits at slaughtering, washed in physiological saline, and fixed in $10 \%$ neutral buffered formalin. The specimens were then dehydrated in ascending grades of ethyl alcohol, cleared in terpinol, washed in benzene, embedded in paraffin wax, sectioned at $5 \mu$, stained with hematoxylin and eosin, and examined microscopically (Delafield, 1984).

\section{Statistical analysis :}

Least Square Maximum Likelihood method of analysis (SPSS, Statistics Users Guide, Version 21) was used to analyze the obtained data according to Snedecor and Cochran(1982) using the formula:

$$
\mathrm{Y}_{\mathrm{ijk}}=\mu+\mathrm{Ti}+\mathrm{e}_{\mathrm{ijk}}
$$


Where: $\mathrm{Y}_{\mathrm{ijk}}$ is any observation, $\mu$ is the overall mean of observation, $\mathrm{Ti}$ is the effect of treatment and $\mathrm{e}_{\mathrm{ijk}}$ is the random error. Duncan's New Multiple Range test was used for multiple comparisons (Duncan, 1955).

\section{RESULTS AND DISCUSSION}

\section{Effect of dietary inclusion of Moringa oleifera hay on: Blood haematological parameters:}

Data in Table 3 showed that rabbits fed Diet $\mathrm{C}$ increased significantly $(\mathrm{P}<0.01)$ haemoglobin $(\mathrm{Hb})$ and hematocrit $(\mathrm{Hct})$ as compared with those fed Diet $\mathrm{B}$ and Diet A (control group). Also means of corpuscular haemoglobin concentration $(\mathrm{MCHC})$ increased significantly $(\mathrm{P}<0.05)$ for growing NZW rabbits fed Diet $\mathrm{C}$ and Diet A (control) than those fed Diet B. However, the differences in red blood cell (RBCs), white blood cell (WBCs), platelet (Plt), neutrophils, lymphocytes, mean corpuscular volume (MCV) and mean corpuscular haemoglobin $(\mathrm{MCH})$ were not significant. Moreover, all values of blood haematological parameters are within the normal range for healthy rabbits. Similar results were obtained by Terzungwe Ahemen et al. (2013) who found that red blood cells (RBCs) concentration, white blood cells (WBCs) concentration, mean corpuscular volume (MCV), mean corpuscular haemoglobin $(\mathrm{MCH})$, mean corpuscular haemoglobin concentration (MCHC) lymphocytes (\%) and neutrophils(\%) were not significant affected in rabbits fed diets containing 5\%, 10\%, and 15\% Moringa oleifera leaves meal as compared to those fed control diet. However, significant effect of the diet containing moringa was observed on haemoglobin $(\mathrm{Hb})$ concentration. Also, Vantsawa and Daramola (2014) observed that haemoglobin $(\mathrm{Hb})$ concentration was significantly $(\mathrm{P}<0.05)$ increased in rabbits fed diets containing $0,5,10$ and 15\% Moringa oleifera leaves meal. However, red blood cells (RBCs) count, white blood cells (WBCs) count, mean corpuscular volume, mean corpuscular haemoglobin concentration, neutrophils and lymphocytes $(\%)$ showed no significant difference $(\mathrm{P}<0.05)$ among the treated groups.

\section{Blood biochemical parameters:}

The differences in total protein, albumin, globulin, A/G ratio, aspartate amino transferase (AST), alanine amino transferase (ALT), bilirubin, urea-N and creatinine among the experimental groups of growing NZW rabbits fed 
Table(3): Means and standard error of blood haematological parameters of growing NZW rabbits fed different level of Moringa oleifera hay (leaves +twigs) as a substitute for alfalfa hay in the diet .

\begin{tabular}{|c|c|c|c|c|c|}
\hline \multirow[t]{2}{*}{ Traits } & \multicolumn{4}{|c|}{ Experimental diets } & \multirow[t]{2}{*}{ Sig. } \\
\hline & Diet A & Diet B & Diet C & Normal range & \\
\hline Haemoglobin (g/dl) & $\begin{array}{l}11.48^{\mathrm{b}} \\
\pm 0.30\end{array}$ & $\begin{array}{l}11.62^{b} \\
\pm 0.07\end{array}$ & $\begin{array}{l}12.09^{\mathrm{a}} \\
\pm 0.51\end{array}$ & $9.4-13.8$ & ** \\
\hline Red Blood cell $\left(\times 10^{6} / \mathrm{ml}\right)$ & $\begin{array}{c}5.62 \\
\pm 0.09\end{array}$ & $\begin{array}{l}5.70 \\
\pm 0.17\end{array}$ & $\begin{array}{l}6.23 \\
\pm 0.33\end{array}$ & $3.80-5.82$ & NS \\
\hline Hematocrit (\%) & $\begin{array}{l}36.50^{\mathrm{b}} \\
\pm 0.43\end{array}$ & $\begin{array}{l}37.20^{\mathrm{b}} \\
\pm 0.98\end{array}$ & $\begin{array}{l}42.36^{\mathrm{a}} \\
\pm 1.57\end{array}$ & $29.8-42.7$ & $* *$ \\
\hline Mean corpuscular volume (fl) & $\begin{array}{l}64.88 \\
\pm 0.60\end{array}$ & $\begin{array}{r}65.30 \\
\pm 1.36\end{array}$ & $\begin{array}{l}68.16 \\
\pm 1.40\end{array}$ & & NS \\
\hline $\begin{array}{l}\text { MeanCorpuscular } \\
\text { Haemoglobin (pg) }\end{array}$ & $\begin{array}{r}20.16 \\
\pm 0.42\end{array}$ & $\begin{array}{r}20.68 \\
\pm 0.33\end{array}$ & $\begin{array}{l}21.22 \\
\pm 0.50\end{array}$ & & NS \\
\hline Mean Corpuscular & $30.86^{\mathrm{b}}$ & $31.12^{\mathrm{ab}}$ & $31.84^{\mathrm{a}}$ & & \\
\hline $\begin{array}{l}\text { Haemoglobin Concentration } \\
\text { (g/dl) }\end{array}$ & \pm 0.17 & \pm 0.26 & \pm 0.26 & & * \\
\hline White blood cell $\left(\times 10^{3} / \mathrm{dl}\right)$ & $\begin{array}{c}7.70 \\
\pm 0.99\end{array}$ & $\begin{array}{c}8.20 \\
\pm 1.08\end{array}$ & $\begin{array}{l}10.70 \\
\pm 1.48\end{array}$ & $2.63-11.87$ & NS \\
\hline Neutrophils (\%) & $\begin{array}{l}28.00 \\
\pm 4.63\end{array}$ & $\begin{array}{l}35.60 \\
\pm 3.54\end{array}$ & $\begin{array}{l}38.00 \\
\pm 7.02\end{array}$ & $11.9-55.10$ & NS \\
\hline Lymphocytes (\%) & $\begin{array}{l}58.60 \\
\pm 0.91\end{array}$ & $\begin{array}{l}49.60 \\
\pm 2.97\end{array}$ & $\begin{array}{l}48.60 \\
\pm 6.15\end{array}$ & $39.8-85.4$ & NS \\
\hline Platelet $\left(10^{9} /\right)$ & $\begin{array}{r}264.40 \\
\pm 28.58 \\
\end{array}$ & $\begin{array}{r}279.00 \\
\pm 28.96 \\
\end{array}$ & $\begin{array}{l}350.80 \\
\pm 26.99 \\
\end{array}$ & $113.8-657.6$ & NS \\
\hline
\end{tabular}

$\mathrm{NS}=$ Not significant, $*=\mathrm{P} \leq 0.05$ and $* *=\mathrm{P} \leq 0.01$

Means in the same raw within the same classification with different litters, differ significantly $(\mathrm{P}<0.05)$.

different level of Moringa oleifera hay were not significant (Table 4). The present results are in agreement with those obtained by Ahemen et al. (2013). They found that the differences among the experimental groups of rabbits fed diets containing 0,5,10 and 15\% Moringa oleifera leaves meal in total protein, albumin, urea $-\mathrm{N}$ and creatinine were not significant. Similarly, Ewuola et al. (2012) reported that the differences in aspartate amino transferas (AST) and alanine amino transferase (ALT) in rabbits fed 5, 10 and 15\% Moringa oleifera leaves meal were not significant. Also, Aboha et al. (2012) found that urea-N 
Table (4): Means and standard error of blood biochemical constituents of growing NZW rabbits fed different level of Moringa oleifera hay (leaves +twigs) as a substitute for alfalfa hay in the diet.

\begin{tabular}{|c|c|c|c|c|c|}
\hline \multirow[t]{2}{*}{ Traits } & \multicolumn{3}{|c|}{ Experimental diets } & & \multirow[t]{2}{*}{ Sig. } \\
\hline & Diet A & Diet B & Diet C & Normal range & \\
\hline \multicolumn{6}{|l|}{ Liver function: } \\
\hline $\operatorname{AST}(\mathbf{U} / \mathbf{L})$ & $\begin{array}{l}46.34 \\
\pm 4.67\end{array}$ & $\begin{array}{c}45.11 \\
\pm 13.42\end{array}$ & $\begin{array}{l}59.86 \\
\pm 7.48\end{array}$ & $14-113$ & NS \\
\hline \multirow[t]{2}{*}{ ALT (U/L) } & 61.90 & 72.92 & 67.94 & $12-67$ & NS \\
\hline & \pm 5.78 & \pm 11.50 & \pm 7.36 & & \\
\hline \multirow[t]{2}{*}{ Total protein (g/dl) } & 6.82 & 7.62 & 8.11 & $5.3-7.0$ & NS \\
\hline & \pm 0.33 & \pm 0.70 & \pm 0.64 & & \\
\hline \multirow[t]{2}{*}{ Albumin (g/dl) } & 3.49 & 3.74 & 4.36 & $2.4-4.5$ & NS \\
\hline & \pm 0.24 & \pm 0.32 & \pm 0.32 & & \\
\hline \multirow[t]{2}{*}{ Globulin (g/dl) } & 3.32 & 3.87 & 3.75 & $2.9-4.9$ & NS \\
\hline & \pm 0.16 & \pm 0.41 & \pm 0.54 & & \\
\hline \multirow[t]{2}{*}{ A/G ratio } & 1.05 & 0.97 & 1.27 & & NS \\
\hline & \pm 0.07 & \pm 0.06 & \pm 0.21 & & \\
\hline \multirow[t]{2}{*}{ Bilirubin (g/dl) } & 0.41 & 0.49 & 0.45 & & NS \\
\hline & \pm 0.06 & \pm 0.03 & \pm 0.02 & & \\
\hline \multicolumn{6}{|l|}{ Kidney function: } \\
\hline \multirow[t]{2}{*}{ Urea-N (mg/dl) } & 15.40 & 16.00 & 15.60 & $9.17-31.73$ & NS \\
\hline & \pm 1.28 & \pm 0.70 & \pm 1.43 & & \\
\hline \multirow[t]{2}{*}{ Creatinine (mg/dl) } & 0.85 & 0.88 & 0.87 & $0.80-2.57$ & NS \\
\hline & \pm 0.02 & \pm 0.02 & \pm 0.02 & & \\
\hline
\end{tabular}

$\mathrm{NS}=$ Not significant.

levels and creatinine were not significantly influenced by Moringa oleifera leaves pellets substituted to a commercial feed at levels of 0,10 and $15 \%$.

\section{Histopathological structure:}

Examined sections from spleen of the rabbits fed Diet A (control group) showed normal parenchymatous organization of white and red pulp. The white pulp consisted of lymphatic nodules of mainly B-lymphocytes and periarterial lymphatic sheath of mainly T-lymphocytes that was surrounded eccentric central artery (Figure 1a). Examined sections from spleen of rabbits fed Diet B showed prominent splenic parenchymatous structure with a large expanse of white pulp (Figure 1b). Rabbit's spleen fed Diet C showed a well-defined 
splenic structure with conspicuous of a large white pulp (Figure 2c). Similar results were reported by Owolabi and Ogunnaike (2014) which showed that white pulps (WP) and the red pulps (RP) are clearly defined for that of the spleen tissue of the control animals. The examined sections also clarified that the spleen tissue is normal in histological presentation and could serve the purpose of a suitable reference. Moreover, the photomicrographs illustrate the spleen issue of the group of animals administered with moringa leaf extract. The pulps are also well defined and the entire tissues structural integrity is normal. The white pulps appear relatively quite prominent. This structure is quite important for the immune roles of the spleen. Observations therefore strongly suggest that moringa leaf extract treatment did not produce any deleterious effect on the spleen tissue structure; however, it could have been structural improvement that could translate into improved physiological functions of the tissue. Moringa has been reported to produce positive effects on the body's immunity (Gupta, 2010).

The liver of the rabbits fed Diet A (control group) showed normal hepatic parenchyma composed of hepatocytes cords that radiated from a central vein. The hepatocytes had a large central located and spherical nucleus with acidophilic cytoplasm (Figure $2 \mathrm{a}$ ).

Examined sections from liver of rabbits fed Diet B showed a welldefined hepatic parenchyma with obvious hepatic sinusoids that were housing kupffer cells (Figure 2b). Also, examined sections from liver of rabbits fed Diets $\mathrm{C}$ showed more prominent and better hepatic parenchyma with clear binucleated hepatocytes and kupffer cells (Figure 3c). these results are in agreement with those reported by Pari et al.( 2002), Buraimoh et al. (2011), Das et al. (2012), Saalu et al. (2012) and Omotoso et al.(2015) who showed that moringa improved liver pararencymal degenerative changes. However, Hamza (2007), Ghebreselassie et al.(2011), Reddy et al.(2013), Olatosin et al.(2013) and Joseph et al. (2015) reported that Moringa supplementation in rabbit diets did not significantly affect histopathological structure of liver. 

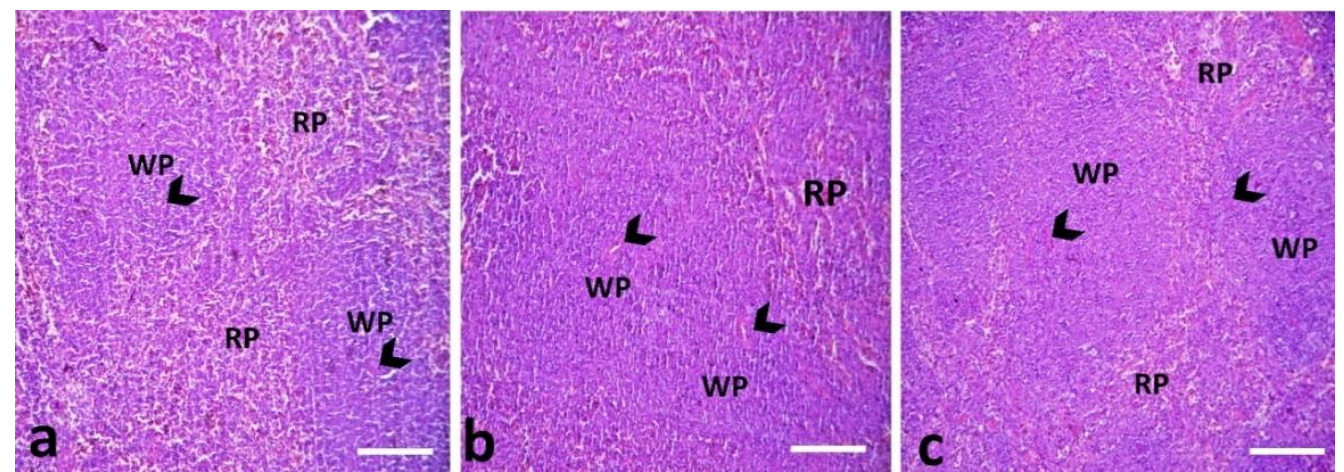

Figure(1): Photomicrographs of spleen for growing NZW rabbits fed different levels of Moringa oleifera hay (leaves + twigs) as a substitute for alfalfa hay in the diet. (a) Control group (Diet A) showing normal splenic structures. (b) Rabbit's spleen fed Diet B showing prominent splenic structure with a large expanse of WP. (c) Rabbit's spleen fed Diet C showing a well-defined splenic structure with conspicuous of a large WP.

White pulp (WP), Red pulp (RP), eccentric central artery (arrowhead).

Stain: H\&E scale bar: $50 \mu \mathrm{m}$
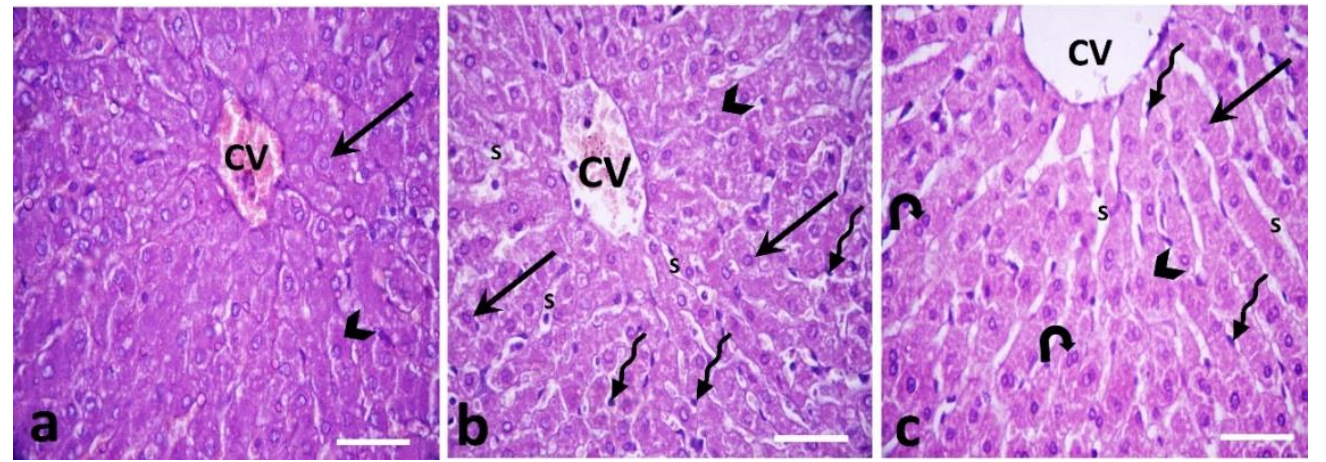

Figure (2): Photomicrographs of liver for growing NZW rabbits fed different level of Moringa oleifera hay (leaves + twigs) as a substitute for alfalfa hay in the diet. (a) Control group (Diet A) showed normal hepatic parenchyma (b) Rabbits fed Diet B showed well defined hepatic parenchyma (c) Rabbits fed Diet C showed more prominent and better hepatic parenchyma.

Central vein (CV), hepatocytes with pale nucleus (arrows) and acidophilic cytoplasm (arrow heads) and some hepatocytes were binucleated (closed arrow), hepatic sinusoids (S), kupffer cells (zigzag arrow).

Stain: H\&E scale bar: $50 \mu \mathrm{m}$ 

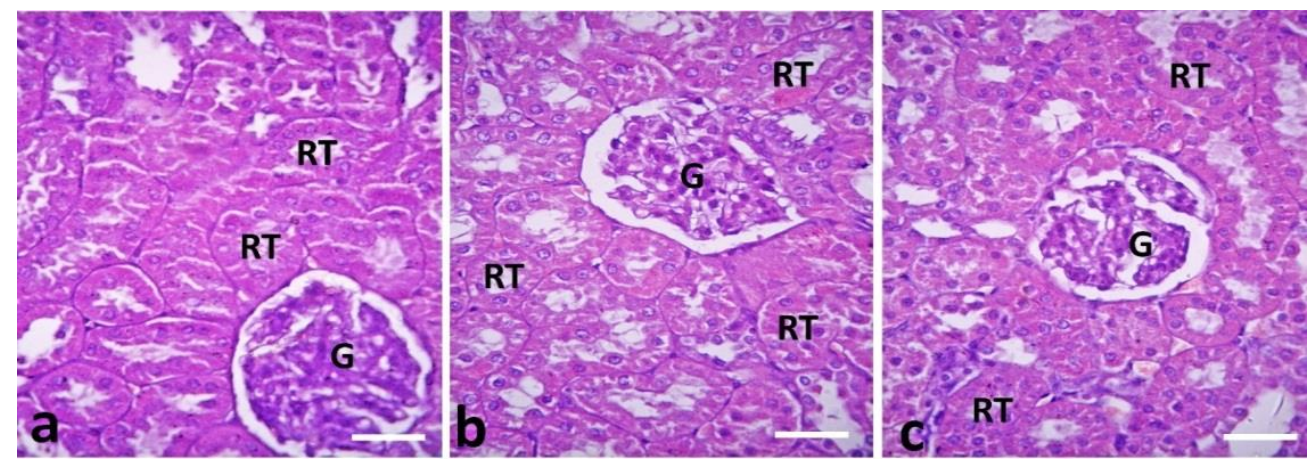

Figure (3) : Photomicrographs of kidney for growing NZW rabbits fed different level of Moringa oleifera hay (leaves +twigs) as a substitute for alfalfa hay in the diet.

(a) Control group (Diet A) showed normal architectures of renal parenchyma

(b) Kidney for rabbits fed Diet B hay showed well defined renal parenchyma

(c) Kidney for rabbits fed Diet $\mathrm{C}$ showed better integrity and clear delineation of renal parenchyma. Glomerulus (G), Renal Tubules (RT),

Stain: H\&E Scale bar: $50 \mu \mathrm{m}$

The kidney of the control rabbit showed normal architectures of renal parenchyma that formed of glomerulus and renal tubules (Figure 3a). Kidney for rabbits fed diets with partial substitution of 50\% Moringa oleifera hay had a well-defined glomerulus and renal tubules (Figure $3 \mathrm{~b}$ ). Kidney for rabbits fed diets with partial substitution of $75 \%$ Moringa oleifera hay showed better integrity and clear delineation of glomerulus and renal tubules (Figure 3c). These results are in agreement with those of Ghebreselassie et al. (2011), Reddy et al.( 2013) and Al-Malki et al.(2015) who found that Moringa supplementation did not significantly affect histopathological structure of kidney.

Sections from testis for male rabbits fed Diet A (control) revealed large number of seminiferous tubules, lined by single basal rounded spermatogonia cells, followed by 2-3 layers of spermatocytes in a different maturation phases. The lumina of the seminiferous tubules are free of any spermatozoa and the interstitial tissue appeared slightly edematous (Figure 4a). Also, examined sections from testis of male rabbits fed Diet B showed normal spermatogonia, spermatocytes and spermatogenesis processes, however, there were mild 


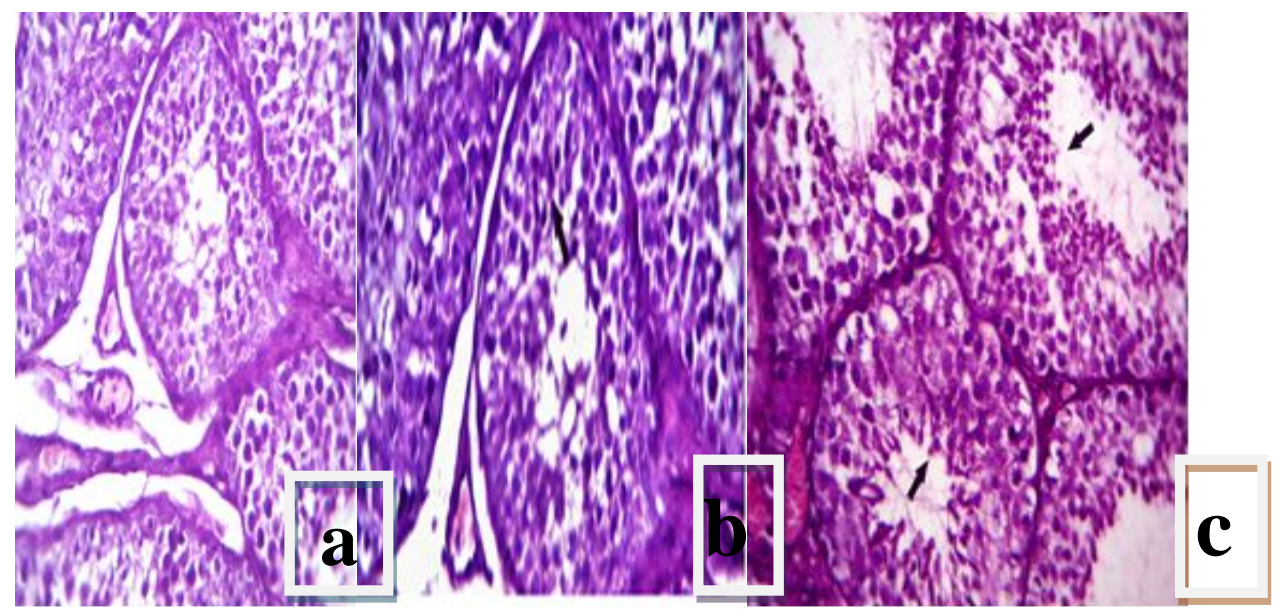

Figure(4): Photomicrographs of testes for growing NZW male rabbits fed different level of Moringa oleifera hay (leaves + twigs) as a substitute for alfalfa hay in the diet. (a) Control group (Diet A) showing seminiferous tubules, lined by spermatogonia, followed by primary and secondary spermatocytes. No spermatids or spermatozoa are seen. (b) Male rabbit's testes fed Diet B showing increase in the mitotic activities of the sprtmatocytic series. (c) Male rabbit's testes fed Diet $\mathrm{C}$ showing highly activated spermatogonia and spermatocytic series with accumulation of increased numbers of secondary spermatocytes on the lumina of seminiferous tubules. ( H\&EX 400).

increases in the mitotic activities of the spermatocytic series (Figure 4b). Examined sections from testis of male rabbits fed Diet $\mathrm{C}$ showed a highly activated spermatogonia and spermatocytic series with accumulation of increased numbers of secondary spermatocytes on the lumina of a large number of seminiferous tubules (60-70\%). The remaining tubules showed normal spermatogenesis (Figure 4c). Similar results were reported by Lilibeth and Glorina (2010) and Prabsattroo et al. (2015) who found that moringa and its components have a protective effect on the testes. Moringa oleifera has positive effect on enhancing spermatogenesis and mature leydig cells in rats and increased the weight of reproductive organs, increases hyperactivity of germinal epithelium cells and in numbers of cells at all stages of spermatogenesis (Varsha et al., 2013), as well as, increased the population of the sperm cells in the lumen of the seminiferous tubules (Paul et al., 2012 

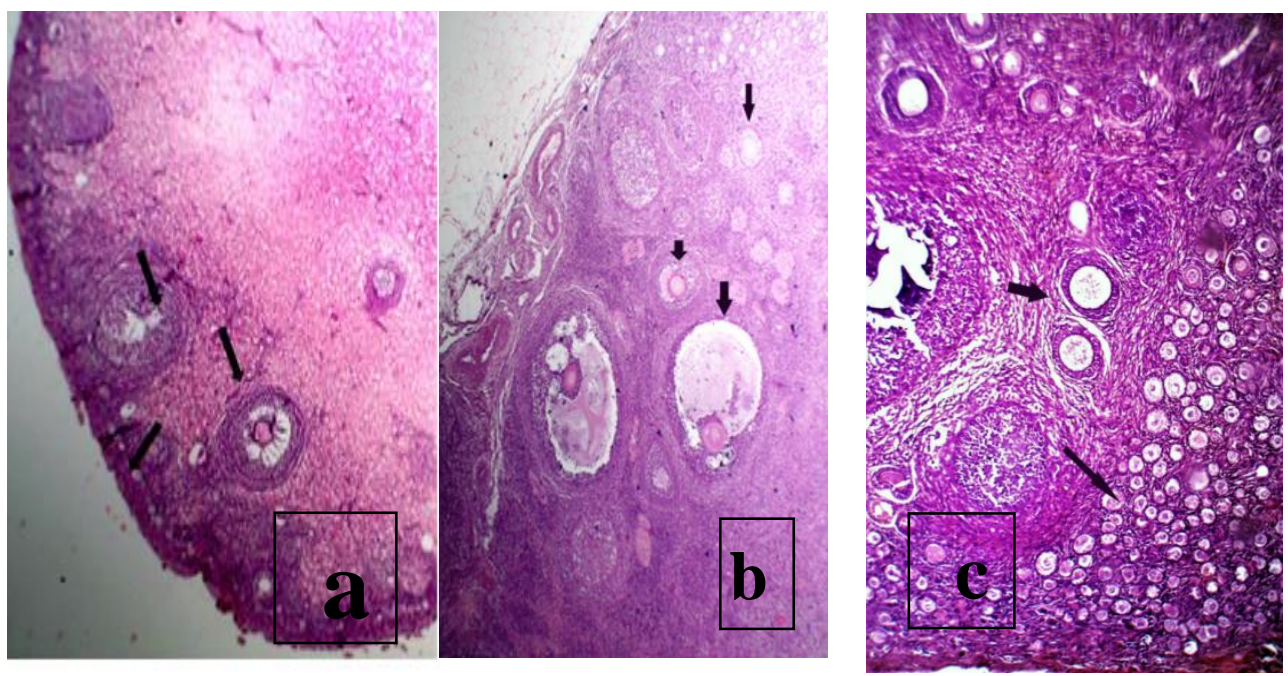

Figure(5): Photomicrographs of ovary for growing NZW female rabbits fed different level of Moringa oleifera hay (leaves + twigs) as a substitute for alfalfa hay in the diet. (a) Control group (Diet A) showing different growing follicles. (b) Female rabbit's ovaries fed Diet B showing a comparatively increased numbers of primordial and growing follicles. (c) Female rabbit's ovaries fed Diet $\mathrm{C}$ showing presence of a moderate numbers of primordial ad growing follicles ( $\mathrm{H} \& \mathrm{EX} 400)$.

and Khalifa, et al., 2016).

Examined sections from ovary of growing female rabbits fed Diet A (control) revealed a normal outer lining cuboidal germinal epithelial layer, stromal structures (vascular, lymphatic, nervous and fibrous tissues) with a moderate number of lipid containing cells (Figure 5 a). The ovarian cortex contained variable numbers of primary, secondary and tertiary follicles. Each of these follicles, showed the above mentioned histological structures (histology overview). Examined sections of ovaries of female growing rabbits fed Diet B revealed presence of primordial and growing follicles, together with normal stromal structures. The numbers of the primordial and growing follicles were more in comparison with that of the control rabbits. (Figure 5b). Examined sections from ovaries of female growing rabbits fed Diet $\mathrm{C}$ showed activated ovarian function with the presence of a moderate numbers of primordial and growing follicles (Figure 5c). The results are in agreement with those reported by 
Shukla et al. (1989) who found that Moringa supplementation increase in the height of luminal epithelium well developed glands, loose stroma and rich vascularity.

Conclusively, results of the present study demonstrated that Moringa oleifera hay (leaves 50\%+ twigs 50\%) can be used as a good source of protein for feeding growing rabbits up to $15 \%$ to replace about $75 \%$ of alfalfa hay without any adverse effects on blood constituents and structure of growing rabbits under environmental conditions of Egypt.

\section{REFERANCE}

Aboha, A. B., Dougnonb, J. T., Gbego Tossa, I., Kpodekonb, M. T., Akakpob, R. P. A. and Youssaob, I. (2012). Growth performance, hematological and serum characteristics of rabbit fed Moringa oleifera leaves pellets as substitute to commercial concentrate. Research Opinions in Animal and Veterinary Sciences, 2(8): 454 - 458.

Ahemen, T., Abu, A.H. and Iorgilim, L. K. (2013). Physiological responses of rabbits fed graded levels of Moringa oleifera leaf meal (MOLM): Some aspects of haematology and serum biochemistry. Archives of Applied Science Research, 2:172-176.

Al-Malki, A. L. and El-Rabey, H. A. (2015). The antidiabetic effect of low doses of Moringa oleifera lam. seeds on Streptozotocin induced diabetes and diabetic nephropathy in male rats. BioMed Research International, 38: 1040.

Amaglo N. K., Bennett R. N., Curto R. B., Rosa E. A. S., Turco V., Giuffrid A., Curto A., Crea F. and Timpo G. M. (2010). Profiling selected phytochemicals and nutrients in different tissues of the multipurpose tree Moringa oleifera L., grown in Ghana. Food Chem. 122 : 1047-1054.

Aslam M F, Anwar R, Nadeem U, Rashid TG, Kazi A and Nadeem M. (2005). Mineral composition of Moringa oleifera leaves and pods from different regions of Punjab, Pakistan. Asian Jornal. Plant.Science, 4 : 417-421.

Bennett RN, Mellon F. A, Foidl .N, Pratt J. H, Dupont M. S, Perkins .L and kroon P .A .(2003). Profiling glucosinolates and phenolics in vegetative tissiue of the multi-purpose tree Moringe oleifera L. (Horseradish tree) and Moringa stenopetala . Journal. of Agriculture . And Food Chem., 51: 3546 3553. 
Buraimoh, A.A., Bako, I.G. and Ibrahim, F.B. (2011). Hepatoprotective effect of ethanolic leave extract of Moringa oleifera on the histology of paracetamol induced liver damage in wistar rats. International Journal of Animal and Veterinary Advances, 3: 10 -13.

Das, N., Kunal, S., Santinath, G., Bernard, F. and Sanjit, D. (2012). Moringa oleifera lam. Leaf extract prevents early liver injury and restores antioxidant status in mice fed with high- fat diet. Indian Journal of Experimental Biology, 50: 404 - 412.

Delafield, F. (1984). Haematoxylin and Eosin For General Staining. Staining Of The Animal Tissues: Practical and Theoretical. London, Oxford University. Press.

Doumas, B.T., Watson, W. A. and Biggs, H. G. (1971). Determination of serum albumin. Journal of Chemical Acta, 31: 87- 89.

Duncan, D.B. (1955). Multiple Range and Multiple F-Test. Biometric, 11: 1- 42.

Emad, El-Eslam, A.T. (1997). Physiological studies on Nigella sativa seed. Master of Science Thesis, Fac. of Agric., Alexandria University, Egypt.

Ewuola, E. O., Jimoh, O. A., Atuma, O. V. and Soipe, O. D. (2012). Haematological and serum biochemical response of growing rabbits fed graded Levels of Moringa oleifera leaf meal. Proceedings $10^{\text {th }}$ World Rabbit Congress, Sept. 3 - 6, 2012, Sharm El-Sheikh-Egypt, 679-683.

Ghebreselassie, D., Mekonnan, Y., Gebru, G., Ergete, W. and Huruny, K. (2011). The effect of Moringa stenopetalla on blood parameters and histopathology of liver and kidney of mice. Ethiopian Journal of Health Development, 25 (1) : 51-57.

Gowrishankar R., Kumar M., Menon V., Divi S. M., Saravanan M., Magudapathy P., Panigrahi B. K., Nair K. G. and Venkataramaniah K. (2010). Trace element studies on Tinospora cordifolia (Menispermaceae), Ocimum sanctum (Lamiaceae), Moringa oleifera (Moringaceae), and Phyllanthus niruri (Euphorbiaceae) using PIXE. Biological . Trace Element. Research, 133, 357363.

Gupta, A., Gautam, M.K., Singh, R.K., Kumar, M.V., Rao, C.h.V., Goel, R.K. and Anupurba, S. (2010). Immunomodulatory effect of Moringa oleifera lam. extract on cyclophosphamide induced toxicity in mice. Indian Journal of Experimental Biology, 48 (11):1157-1160. 
Hamza, A.A. (2007). Curcuma longa, Glycyrrhiza glabra and Moringa oleifera ameliorate diclofenac-induced hepatotoxicity in rats. American Journal of Pharmacology and Toxicology, 2: 80-88.

Henry, R.J. (1964). Colorimetric determination of total protein. Clinical Chemistry. Harper and Row Publishers, New York,PP:181.

Henry, R.J. (1974): Clinical chemistry, principles and techniques, 2nd edition, Harper and row, pp: 525.

Joseph, I. I., Eru, E., Mba, F., Victor, A., Uruakpa, K., Chinkata, E. and Effiom, O. (2015). Cytoarchitectural distortion of the liver follwing the administration of aqueous Moringa oleifera seed on acetaminophen induced hepatotoxicity in Wistar rats. European Journal of Educational and Development Psychology, 3 (1): 14-20.

Khalifa, W. H., Faten, M. Ibrahim, Aida, I. El Makawy, Hafiza, A., Sharaf., Wagdy, K. B. K. and Nagwa, A. Maghraby. (2016). Safety and fertility enhancing role of Moringa oleifera leaves a005Aqueous extract in New Zealand rabbit bucks. International Journal Pharmacy, 6 (1): 156-168.

Lilibeth, A. C. and Glorina, L. (2010). Effects of Moringa oleifera Lam. (Moringaceae) on the reproduction of male mice (Mus musculus). Journal of Medicinal Plants Research, 4 (12):1115-1121.

Manguro L. O. And Lemmen, P. (2007). Phenolics of Moringa oleifera leaves. Natural. Product. Research, 21: 56 - 68

NRC (1977). Nutrients Requirements of Domestic Animals. Nutrients Requirements of Rabbits. $2^{\text {nd }}$ Edition. National Research Council, National Academy of Science. Washington, DC. United States of America.

Olatosin, T.M., Akinduko, D.S. and Uche, C.Z. (2013). Evaluation of the hepatoprotective efficacy of Moringa oleifera seed oil on CCl4-iinduced liver damage in Wistar albino rats. The International Journal of Engineering and Science, 2: 13-18.

Owolabi, J. O. and Ogunnaike, P. O. (2014). Histological evaluation of the effects of moringa leaf extract treatment on vital organs of murine models. Merit Res. J. of Medicine and Medical Sciences, 2 (10): 245-257.

Patton, C.J. and Crouch, S.R. (1977). Calorimetric determination of serum urea. Analytical. Chemistry, 49: 464 - 469. 
Paul, C.W. and Didia, B.C. (2012). The effect of Methanolic extract of Moringa oleifera Lam roots on the histology of kidney and liver of Guinea Pigs. Asian Journal of Medical Sciences, 4(1): 55-60.

Prabsattroo, T., Jintanaporn, W. and Sitthichai, I. (2015). Moringa oleifera extract enhances sexual performance in stressed rats. Journal Zhejiang University Sciences B (Biomed \& Biotechnol), 16 (3):179-190.

Reddy, R.R. Y., Lokanatha, O., Ratnam, K. S. V. P., Shanmuga, R.N. and Damodar, R.C. (2013). Acute and sub-acute toxicity of Moringa oleifera stem bark extral 'ct in Swiss albino mice. International Journal Life Sciences biotechnology \& Pharmaceutical Research, 2 (4): 73-82.

Reitman, S. and Frankel, S. (1957). A calorimetric method for the determination of serum glutamic oxalactic and glutamic pyruvic transaminase. American. Journal Clinical Pathology, 28: 56 - 63.

Shukla, S., Mathur, R. and Prakash, A.O. (1989). Biochmical alterations in the female genital tract of ovariectomized rats treated with aqueous extract of Moringa oleifera lam. Pakistan. Journal of Scientific and Industrial Research, 32 (4): 273-277.

Siddhuraju P. and Becker K. (2003). Antioxidant properties of various solvent extracts of total phenolic constituents from three different agro-climatic origins of drumstick tree (Moringa oleifera Lam.) leaves. Journal of Agricultural and Food Chemistry, 51: 2144 - 2155.

Snedecore, G.W. and W.G. Cochran, 1982. Statistical Methods. $6^{\text {th }}$ ed. Iowa State University Press. Ames, Lowa, U.S.A.

Vantsawa, P. and Daramola, A. (2014). The effect of Moringa oleifera leaf meal (MOLM) on the hematological parameters and the cholesterol level of rabbits. American Journal of Biological, Chemical and Pharmaceutical Sciences, 2 : 1-6.

Varsha, S. Z., Dinesh, K. D., Vaibhao, G. T. and Shital, R. P. (2013). Effect of aqueous extract of Moringa oleifera seed on sexual activity of male albino rats. Biological An International Journal, 5(1): 129-140. 


\title{
إستخدام دريس المورينجا أوليفيرا كعلف جليد للارانب ـ 4ـ تأثر أدخال

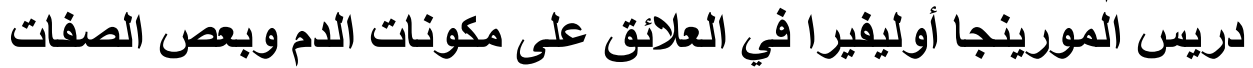

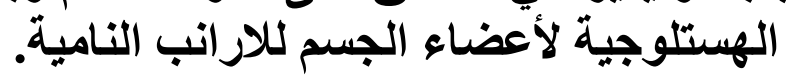

\author{
محمود سعد محمد عبدالله - حسن إبراهيم على - حسن محمود الكيلاوى, محمد ناجى الجعفرى \\ قسم الانتاج الحيو انى و الداجنى ـ كلية التكنولوجيا و التنمية - جامعة الزقازيق.
}

إستخدم فى هذة الدراسة 90 أرنب نيوزيلندى أبيض مفطوم عمر خمسة أسابيع متوسط وزن أرنا

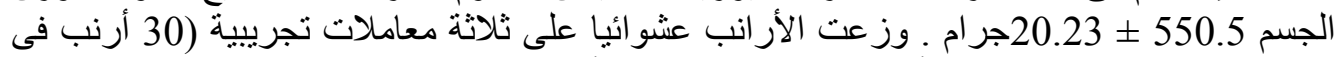

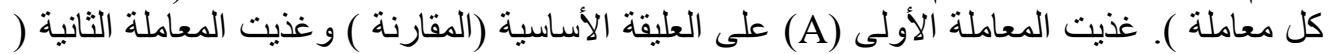

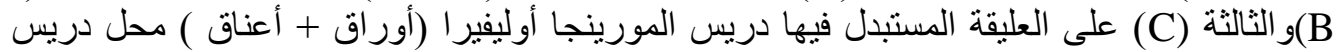

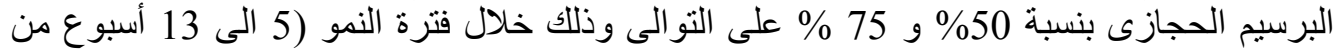
العمر ) تم دراسة مكونات الدم وبعض الصفات الهستلوجية لأعضاء الجسم فى الار انب النيوزيلندى

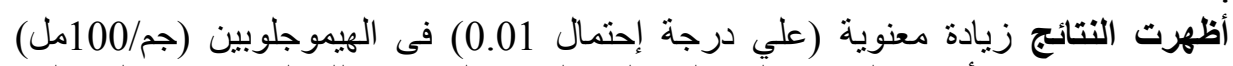

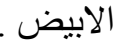

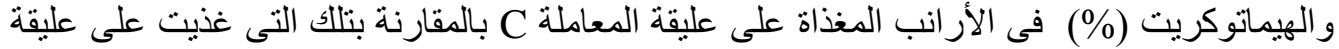

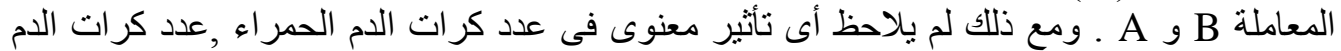

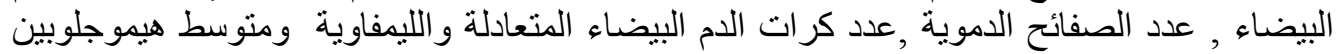

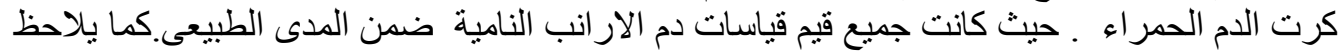

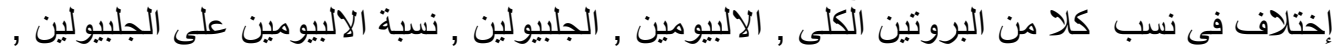

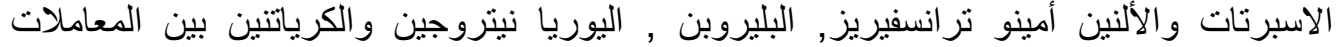

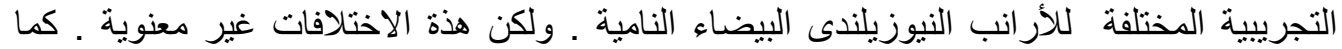

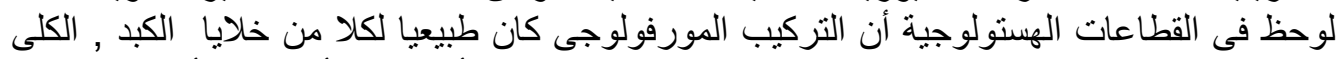

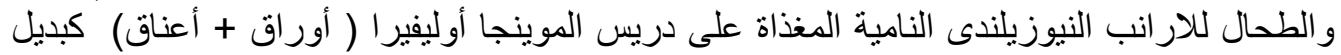

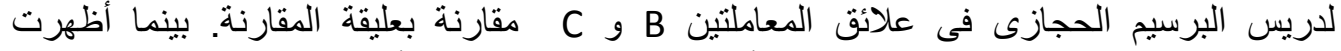

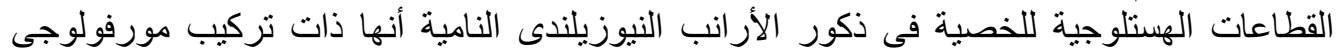

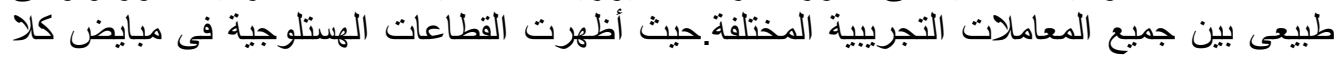

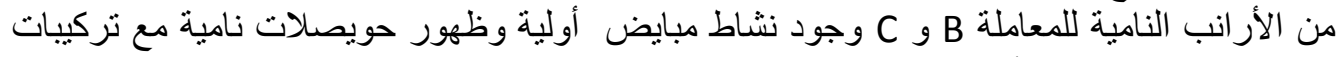

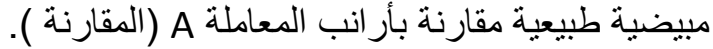

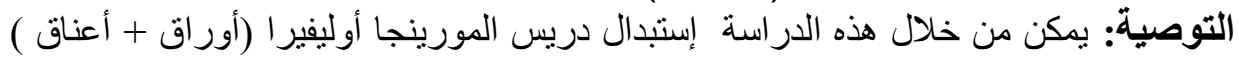

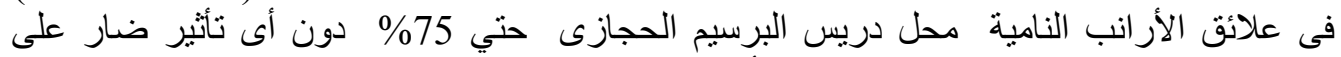
مكونات الدم وبعض الصفات الهستلوجية لاعضاء الجسم للار انب النيوزلندى البيضاء النامية تحت

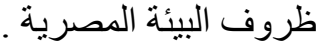

